University of Nebraska - Lincoln

DigitalCommons@University of Nebraska - Lincoln

2012

Detecting changes in climate forcing on the fire regime of a North American mixed-pine forest: A case study of Seney National Wildlife Refuge, Upper Michigan

Igor Drobyshev

Université du Québec en Abitibi-Témiscamingue, Igor.Drobyshev@uqat.ca

P. Charles Goebel

Ohio State University, cgoebel@uidaho.edu

Yves Bergeron

Université du Québec en Abitibi-Témiscamingue

R. Gregory Corace III

U.S. Fish and Wildlife Service

Follow this and additional works at: http://digitalcommons.unl.edu/usfwspubs

Drobyshev, Igor; Goebel, P. Charles; Bergeron, Yves; and Corace, R. Gregory III, "Detecting changes in climate forcing on the fire regime of a North American mixed-pine forest: A case study of Seney National Wildlife Refuge, Upper Michigan" (2012). US Fish \& Wildlife Publications. 434.

http://digitalcommons.unl.edu/usfwspubs/434

This Article is brought to you for free and open access by the US Fish \& Wildlife Service at DigitalCommons@University of Nebraska - Lincoln. It has been accepted for inclusion in US Fish \& Wildlife Publications by an authorized administrator of DigitalCommons@University of Nebraska - Lincoln. 


\title{
Detecting changes in climate forcing on the fire regime of a North American mixed-pine forest: A case study of Seney National Wildlife Refuge, Upper Michigan
}

\author{
Igor Drobyshev $^{\mathrm{a}, \mathrm{b}, *}$, P. Charles Goebel ${ }^{\mathrm{c}}$, Yves Bergeron $^{\mathrm{a}}$, R. Gregory Corace III ${ }^{\mathrm{d}}$ \\ a Université du Québec en Abitibi-Témiscamingue, 445 boul. de l'Université, Rouyn-Noranda, QC, Canada J9X5E4 \\ ${ }^{\mathrm{b}}$ Swedish University of Agricultural Sciences, Southern Swedish Forest Research Centre, Box 49, 23053 Alnarp, Sweden \\ ' School of Environment and Natural Resources, Ohio Agricultural Research and Development Center, The Ohio State University, 1680 Madison Ave., Wooster, OH 44691, \\ United States \\ d U. S. Fish and Wildlife Service, Seney National Wildlife Refuge, 1674 Refuge Entrance Rd., Seney, MI 49883, United States
}

\section{A R T I C L E I N F O}

\section{Article history:}

Received 7 July 2010

Accepted 15 July 2011

\section{Keywords:}

Historical fire regimes

Fire scars

Top-down controls

Fire suppression

Natural disturbances

Hemi-boreal

Climate variability

\begin{abstract}
A B S T R A C T
The study of forests dominated by red pine (Pinus resinosa Ait.), one of the few fire-resistant tree species of eastern North America, provides an opportunity to reconstruct long-term fire histories and examine the temporal dynamics of climate forcing upon forest fire regimes. We used a 300-year long spatially explicit dendrochronological reconstruction of the fire regime for Seney National Wildlife Refuge (SNWR, 38,531 ha), eastern Upper Michigan to: (1) identify fire size thresholds with strong vs. weak climate controls, (2) evaluate effect of landform type (outwash channel vs. sand ridges) in modifying climate-fire associations, and (3) check for the presence of temporal changes in the climate control of large fire events over the time period 1700-1983. We used a summer drought sensitive red pine chronology (ITRDB code can037) as a proxy of past fire-related climate variability. Results indicated that fires $>60$ ha in sand-ridgedominated portions of SNWR and $>100$ ha in outwash channels were likely climatically driven events. Climate-fire associations varied over time with significant climate-fire linkages observed for the periods 1700-1800 (pre-EuroAmerican), 1800-1900 (EuroAmerican settlement) and 1900-1983 (modern era). Although an increase in fire activity at the turn of 20th century is commonly associated with human sources of ignitions, our results suggest that such an increase was also likely a climatically driven episode.
\end{abstract}

(C) 2012 Istituto Italiano di Dendrocronologia. Published by Elsevier GmbH. All rights reserved.

\section{Introduction}

Fire disturbances in boreal forests exhibit large temporal and spatial variability, reflecting complex interplays of factors responsible for fire initiation and propagation (Stocks and Lynham, 1996; Niklasson and Granström, 2000; Flannigan and Wotton, 2001; Bergeron et al., 2004). Geographically large climatic patterns control regional $\left(10^{6-9}\right.$ ha) fire activity (Flannigan and Wotton, 2001; Girardin, 2007), whereas landscape-specific features like landforms, ignition patterns, and fuel properties are important at finer scales ( $<10^{6}$ ha) (Hely et al., 2000; Cary et al., 2006; Drobyshev et al.,

\footnotetext{
* Corresponding author at: Swedish University of Agricultural Sciences, Southern Swedish Forest Research Centre, Box 49, 23053 Alnarp, Sweden. Tel.: +46 40415199.

E-mail addresses: Igor.Drobyshev@uqat.ca, igor.drobyshev@slu.se (I. Drobyshev).
}

2008a,b). Although there is a general agreement on the hierarchical structure of the mechanisms controlling fire regimes (Morgan et al., 2001), it is often difficult to provide a more precise estimate of size threshold, separating two above-mentioned modes of fire activity. Studies of fire regimes both in Eurasia and North America repeatedly demonstrate that large and climatically driven fires contribute to the majority of the area burned during a time period (Stocks et al., 2002; Balzter et al., 2005). Conversely, small, and typically low-intensity fires, although being relatively insignificant in the total amount of burned area, may result in decreasing severity and intensity of subsequent fires (Arseneault, 2001; Lecomte et al., 2006). Because these low severity fires too are closely connected to population dynamics of many species of flora and fauna (Bergeron and Brisson, 1990; Jonsell et al., 1998; Smirnova et al., 2008), it is therefore of interest to better identify thresholds in climatic influence on local fire regimes and, specifically, quantify the extent of climatic controls along the fire size (area) gradient within a single 
landscape. This information can further advance our understanding of the past disturbance histories and better connect climatic variability with forest ecosystem dynamics. However, to the best of our knowledge, no study has taken advantage of spatially explicit fire history reconstructions to explore historical aspect of this relationship in eastern North America.

Long and spatially explicit dendrochronological reconstructions of past fire regimes can be a helpful tool to resolve climate-weather interactions at annual and even seasonal timescales. In contrast to point reconstructions, a spatial reconstruction allows filtering of a series of fire events as a function of their size, which is assumed to generally reflect the degree of climatic forcing upon a single fire event (Falk and Swetnam, 2002). To explore this relationship in the context of forests of eastern North America, we analyzed fire history data from Seney National Wildlife Refuge (SNWR; Fig. 1), an area in the eastern Upper Peninsula of Michigan, U.S. Much of the SNWR was historically dominated by upland mixed-pine (Pinus spp.) forest ecosystems (Zhang et al., 2000), growing on two major landform types: outwash channels and sand ridges ("islands", sensu Heinselman, 1965). These two landform types are interspersed in a matrix of patterned fens and other wetland types located on a lacustrine plain (Heinselman, 1965). SNWR mixed-pine forest ecosystems reflect the legacy of natural disturbance regimes prior to EuroAmerican settlement of the area, the period of extensive forest use at the time of the Great Cutover (end of 19th and beginning of 20th century, Dickmann and Leefers, 2003). They also reflect the shift in 20th century forest management oriented towards multiple goals, including ecosystem restoration, conservation, and preservation within a wildlife context (Corace et al., 2009; USFWS, 2009). Therefore, the fire history of the area was likely affected by a mixture of climatic and human factors whose relative importance varied over time.

In this study, we address three objectives: (1) identify fire size thresholds with strong vs. weak climate controls, (2) evaluate the effect of landform type (outwash channel vs. sand ridges) in modifying climate-fire association, and (3) examine the presence of temporal changes in the climate control of large fire events over 1700-1983. Two independent datasets were analyzed, including a spatially explicit reconstruction of the SNWR fire history (Drobyshev et al., 2008a) and a drought-sensitive chronology of red pine (Pinus resinosa Ait. chronology can037 of ITRDB, http://www.ncdc.noaa.gov/paleo/treering.html) as an independent proxy for historic fire-related climate variability.

\section{Study area}

SNWR lies within the Seney Sand Lake Plain Sub-Subsection of eastern Upper Michigan, where poorly drained landforms of lacustrine origin prevail (Albert, 1995). The terrain is characterized by outwash channels and patterned fens interspersed by sand ridges (Silbernagel et al., 1997). This matrix was formed by the deposition of Valders glacial outwash, subsequent inundation by earlier stages of the Great Lakes, and drainage of the area during the postAlgonquin period (i.e., 10,000 years BP) (Heinselman, 1965). Across the Seney Sand Lake Plain, the distribution of mixed-pine forest ecosystems tends to be limited to both the outwash channel and sand ridge landforms. At SNWR, outwash channels are typically linear landform types that are associated with streams, approximately 6-8 km long, and 100-1000 m wide. Sand ridges, however, are smaller features ranging from $<0.5$ to 5 ha, with most being $\sim 0.5-2$ ha and several meters in elevation above the surrounding area.

The climate of the Seney Sand Lake Plain is continental, but also strongly influenced by both Lake Superior and Lake
Michigan. The long-term (1971-2000) average annual temperature is $6.2^{\circ} \mathrm{C}$ (MRCC, 2007), with considerable variation between the coldest (January, long-term average minimum temperature, $-13.6^{\circ} \mathrm{C}$ ) and the warmest (July, long-term average maximum temperature, $26.7^{\circ} \mathrm{C}$ ) months. Total annual precipitation is $781 \mathrm{~cm}$, most of which occurs in the form of rain. Approximately $312 \mathrm{~cm}$ in snowfall falls on average per year. Precipitation tends to peak in July $(93.7 \mathrm{~cm})$ and be lowest in February $(30.2 \mathrm{~cm})$. The length of growing season averages 119 days, with evaporation of $64 \mathrm{~cm}$. Average humidity varies from 50 to $60 \%$ from spring through fall. Long-term wind data suggest that during the spring and summer months dominating winds are from the southwest and northwest (USFWS, 2009).

Sedge- and shrub-dominated ecosystems, along with mixed coniferous-deciduous forests, dominated the pre-EuroAmerican landscape at SNWR (Comer et al., 1995; Zhang et al., 2000). Particularly, many areas of SNWR were historically dominated by mixed-pine forest ecosystems comprised red pine, but with a lesser component of eastern white pine (P. strobus L.) and jack pine (Pinus banksiana Lamb.) (Heinselman, 1965; Comer et al., 1995). Presently, SNWR is characterized by a wetland-upland mosaic of forest and non-forest cover types (Corace et al., 2009; USFWS, 2009). The wetland vegetation is typically a sedge- and shrub-matrix. Upland areas characterized by ice-contact landforms are dominated by conifers (e.g., red pine, eastern white pine, jack pine, black spruce (Picea mariana (Mill.) B.S.P.)), while a smaller area of morainal landforms is dominated by deciduous species (e.g., American beech (Fagus grandifolia Ehrh.), sugar maple (A. saccharum Marshall), yellow birch (Betula alleghaniensis Britton)).

Prior to EuroAmerican settlement, fires in conifer forests of the Upper Great Lakes originated from both lightning and anthropogenic sources (Loope and Anderton, 1998). However, by 1851, the General Land Office had completed its surveys in eastern Upper Michigan (Barnett, 1982), and land sales began shortly thereafter. Subsequently, EuroAmerican settlement began and large areas were harvested for timber as well as cleared for agricultural land uses (Losey, 2003). Extensive and intense slash fires resulted (Dickmann and Leefers, 2003). Maybee (1960) suggests that the approximate onset of logging at SNWR was 1860, focusing first on red pine and then eastern white pine sawtimber. Following this exploitive period, many areas were drained and cleared for agriculture. However, poor soil quality and the large scale forest fires fueled by logging debris thwarted these efforts (Losey, 2003). This period of exploitation lasted until the early 1930s, when much of this land was abandoned and tax-reverted to the State of Michigan. In 1935, SNWR was established and forest management practices were undertaken to foster wildlife habitat (Corace et al., 2009; USFWS, 2009).

\section{Methods}

\section{Field data collection}

Field sampling was designed to allow reconstruction of the fire histories of the two major landform types of the 38,531 ha SNWR landscape: (1) sand ridges interspersed within patterned fens, and (2) outwash channels. The majority of the former landform type was located within the federally designated Seney Wilderness Area (hereafter, Wilderness), a 10,178-ha portion of SNWR where remnant old-growth mixed-pine forest ecosystems dominated by red pine remain and where wildfires have occurred within the last $30+$ years. This area is one of the best remaining examples of oldgrowth mixed-pine forest ecosystems in the ecoregion and, more broadly, the Upper Great Lakes region. In the red pine-dominated 


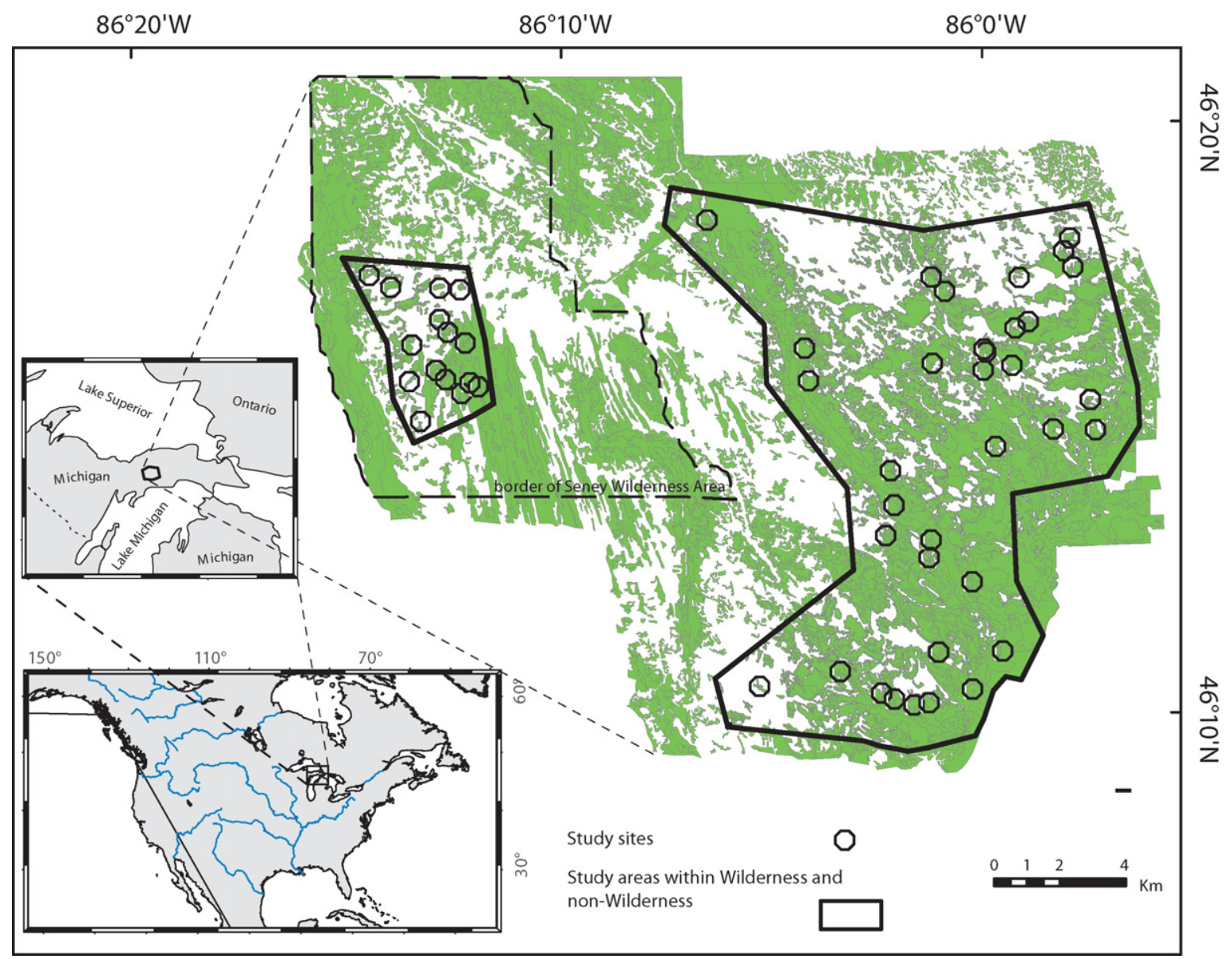

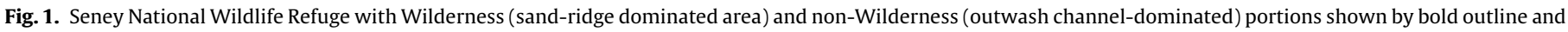

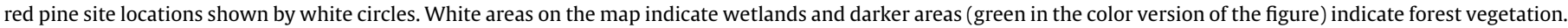
(For interpretation of the references to color in this figure legend, the reader is referred to the web version of the article.)

sand ridges of the Wilderness, the extensive wetland shrub matrix precluded logging as access for horses or machinery was difficult or even impossible. Conversely, the terrain of the non-Wilderness (i.e., outwash channels) did not constrain logging to the same degree as in the Wilderness, and records of timber harvesting exist for this part of SNWR since 1935 (Rist, 2008). Our fire history sampling took place in the areas with different levels of human impact (low in the Wilderness vs. high in the non-Wilderness), and different landform types. In searching for stands to be sampled, we avoided sites where the absence of fire-scarred trees, logs, and stumps precluded fire history reconstruction (Swetnam and Baisan, 1996). Such areas were typically young stands originated after forest harvesting activities of the late 19th century and the first half of the 20th century. Since such stands were interspersed among older sites with fire-scared trees or deadwood, the overall bias in reconstruction of the fire areas due such sampling strategy appeared limited. In each sampled site we searched for fire-scarred live trees, stumps, and snags, and used the method of "wedge sampling" (Swetnam, 1996) to extract a wedge from the bole of trees or other areas containing scars on the stumps and snags. Trees representing the oldest cohorts within the site were typically sampled to recover scars not visible from outside of the trees (so-called overhealed scars). At each site, we searched over an area $\leq 1$ ha (or smaller in the islands with the total area $<1 \mathrm{ha}$ ) and also limited our maximum search time for potential samples to $2.5 \mathrm{~h}$ in order to ensure that our sampling effort did not lead to differences in the probability of detecting past fires among sites. See further details of our sampling strategy in Drobyshev et al. (2008a). In the majority of cases (97\%), the samples were collected from red pine; other tree species from which samples were taken included jack pine and eastern white pine. During the 18th century, each year was represented by an average of 14.5 and 16.6 sites in the sand ridge and outwash channel landforms, respectively. Respective values for the 19th century were 15.0 and 30.1 , and for the 20th century - 15.0 and 33.0 sites. In total, 15 sites were sampled on sand ridges and 41 sites on outwash channels (Fig. 1). See further details of sampling procedures in Drobyshev et al. (2008a).

\section{Sample preparation and dating}

Samples were mounted on wood and progressively polished with up to 400-grit sandpaper to allow clear recognition of annual rings and fire scars under a binocular microscope (using $40 \times$ magnification). All samples were crossdated using a visual approach, following Stokes and Smiley (1968), which included skeleton plots for each sample. We developed local chronologies for sites at SNWR. The master chronology (also referred to as a pointer-year chronology, Schweingruber et al., 1990), utilized ring widths, early- and latewood widths, and late- and earlywood densities. The resulting pointer-year chronology provided a basis for accurate dating of each sample. Additionally, we utilized a number of existing red pine chronologies, which 
were helpful in the verification of our pointer year chronology, available for the region from the International Tree-Ring Data Bank (http://www.ncdc.noaa.gov/paleo/treering.html). Such an approach has been used in several North American and European studies of fire history (e.g., Caprio and Swetnam, 1993; Niklasson and Granström, 2000; Brown, 2006). After crossdating of tree rings was completed on a fire-scarred sample, calendar dates and seasonal information were obtained for all fire scars. Finally, after all samples were crossdated and aged, it became possible to use known fire dates from the studied stands (and especially the dates of large fires in the area such as the 1976 Seney Fire,) as an additional step to verify crossdating accuracy (Anderson, 1982). To deduce the size of past fires, we mapped and analyzed the locations of recording sites (sites with information on the presence/absence of fire) for each fire year reconstructed. We used topographic and vegetation maps to identify natural fire breaks (e.g., streams, local depressions in the terrain, and shrub-dominated areas) that were considered as likely borders of the fires between two recording sites with and without fire recorded for the year in question. See further details in Drobyshev et al. (2008a). Historical fires were spatially reconstructed over the period 1700-2003.

\section{Selecting climate proxy}

As a measure of fire-related climate, we used Monthly Drought Code (MDC), Drought Index (DI), and Seljaninov hydrothermal coefficient (SEL). MDC (Girardin and Wotton, 2009) is a monthly version of Drought Code (DC), a component of the Canadian Forest Fire Weather Index System (Van Wagner, 1987) representing average moisture content of deep organic layers (Turner, 1972). DI is the ratio of actual evapotranspiration to equilibrium evapotranspiration (AET/EET) and is a measure of growing-season drought, calculated in bioclimatical model STASH (Prentice et al., 1993). SEL is an aridity index, directly proportional to cumulative amount of precipitation and inversely proportional to the average temperature during a defined period (Seljaninov, 1966). These proxies for fire-related weather were calculated for SNWR for the period 1900-2003.

Several tree-ring based proxies of historical climate were screened to select the one representing past fire-related weather variability at SNWR over the period covered by the 300 -year long fire reconstruction (Drobyshev et al., 2008a). They included reconstruction of regional fire activity of Canadian Boreal shield (Girardin et al., 2006), North American drought and summer PDSI reconstructions (Cook et al., 1999), and single tree-ring chronologies contributed to above-mentioned reconstructions (ITRDB, http://www.ncdc.noaa.gov/paleo/treering.html). To select fire weather proxy for climate-fire analyses, correlations of respective chronologies with fire weather and drought indices were assessed in response function analysis (Cook and Kairiukstis, 1990). Response function coefficients, in contrast to the Spearman and Pearson correlation coefficients, are produced using principal component regression analysis (Biondi and Waikul, 2004), which removes autocorrelation present in the climatic data. The response function coefficients were tested using the bootstrap method (Efron and Tibshirani, 1993) for their statistical significance. This bootstrap method included (1) random re-sampling of the original dataset with replacement, (2) generating a statistical distribution of a response coefficient, and (3) calculating its $2.5 \%$ and $97.5 \%$ distribution limits. Finally, the value obtained from the original dataset was compared with the bootstrap-generated distribution limits to assess the significance of the coefficient's departure from zero at the 0.05 probability level.

As a result of these screening and preliminary analyses of firegrowth association, we selected chronology can037 originating from a site at Temagami Lake, northeastern Ontario, Canada $(47 \mathrm{~N}, 79 \mathrm{~W})$. The chronology showed consistently high values of Expressed Population Signal, which remained above 0.87 over the whole period analyzed in the current study (1700-1983). We used site residual chronology obtained in ARSTAN program (GrissinoMayer et al., 1997). Tree-ring chronologies from single trees were detrended by using a smoothing spline, which preserved $50 \%$ of the variance at a wavelength of 128 years in ARSTAN program. Each tree ring curve was modeled as an autoregressive process with the order selected by the first-minimum Akaike Information Criterion (AIC). Index values for site and regional chronologies were computed by the division of the original tree curve values. For the period studied, chronology EPS value and rbar statistics stayed above 0.872 and 0.308 , respectively.

\section{Statistical analysis of climate-fire relationships}

To identify fire size thresholds separating fires with strong vs. weak climate controls we evaluated departures of selected residual red pine chronology for different sets of fire years, their selection based on the amount of area burned in those years. The primary reason of not considering ARSTAN chronology for superimposed epoch analyses and for a continuous reconstruction of fire activity was our experience with red pine chronologies from natural forests and awareness that different disturbance agents (e.g., fire) and withinstand interactions (e.g., changes in stand density) could strongly influence low-frequency variability in the used red pine chronology. With no access to the original samples and sampled trees we could not properly assess the level of these impacts. Secondly, it is the higher frequency variability (single year climatic anomalies behind fire years), which was the focus of analyses. In contrast to the situations in more southerly regions of North America, the eastern Upper Peninsula of Michigan is an area with considerable snow accumulation during the coldest period of the year (MRCC, 2007). This should effectively remove potential effects of previous years' conditions on current year fire hazard. In the context of our analysis it would mean that changes in, for example, average decadal fire hazard should not affect strength of climate-fire link in a particular year simply due to the fact that soil and fuel water reserves are recharged each winter.

Initial analyses were conducted on the complete list of fire years. Subsequent analyses used a sub-set of fire years with an increasingly restrictive filter, leaving out years with amount of burned area below a specific threshold. Significance of departures was estimated in Superimposed Epoch Analysis (SEA) performed in EVENT program (Holmes, 1999). Selected fire years were considered as focal years for the purposes of SEA, with the time frame set to 11 years.

Threshold size in minimum annually burnt areas was regressed against departures of residual chronology and parameters of non-linear equation were estimated by Gauss-Newton method (Marquardt, 1963).

For the analysis of temporal changes in climate forcing we used only fires years with the annual burned area $>100$ ha, including fires reconstructed over the whole area of SNWR. Hundred year intervals overlapping by 50 years were used in the SEAs with residual red pine chronology.

\section{Results}

In total, we collected 97 wedge samples in the sand ridge dominated part of the area, with the average, minimum, and maximum number of samples per site equal to $6.5,1$, and 12 , respectively. For sites located in the outwash channel dominated portion of the 


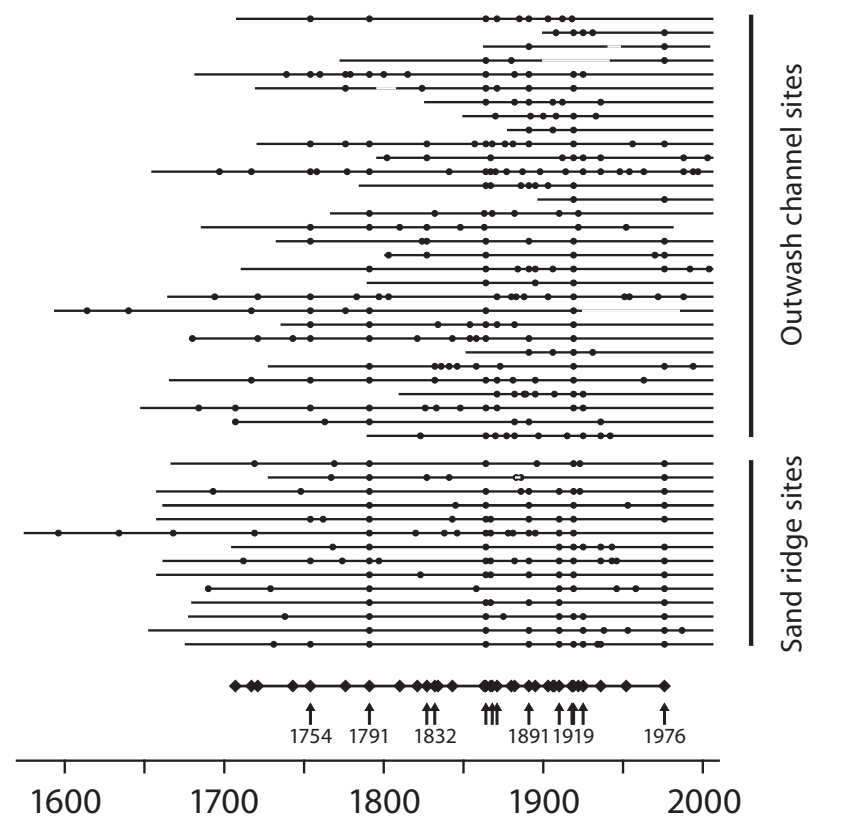

Fig. 2. Fire history and large fire years at Seney National Wildlife Refuge over 403 years (1600-2003). Fire history of single sites is shown as line with dots representing fire events. A blank space indicates a hiatus in a chronology (i.e., stand was not recording during that period). Summary graph at the bottom of the figure shows years with single fire events exceeding 200 ha (diamonds) and 500 ha (arrows). The six largest fire years (more than 3000 ha burned) are labeled.

landscape, the total number of samples was 151 and the average number of samples was 4.6 samples, with the minimum and maximum values being 1 and 12, respectively. Overall, 686 fire scars were dated, corresponding to a total of 410 site-level fire events (Fig. 2). The earliest dated fire occurred in the late growing season of 1596. Spatial reconstruction suggested 217 individual fires over the period of 1707-2003.

We identified seven major fire years for the entire SWNR landscape. During these events, the area burned exceeded 20\% of the total study area (38,531 ha). The major fire years were 1754,1791 , 1864, 1891, 1910, 1919, and 1976 (Fig. 2). Of these, years 1910 and 1976 were recorded as major fire years only within the sand ridge dominated area. In the case of the fire of 1976, this was likely due to active wildfire suppression, since it was actively suppressed in the non-Wilderness part of the area (Anderson, 1982). The year 1754 was a major fire year only in the outwash channel-dominated part of the area. Small ( $<100$ ha) fires dominated the fire regime in both landform types over the entire period with available fire history reconstruction (1707-2006), but it was large fires which contributed to the larger part of the area burned (Drobyshev et al., 2008a).

The tree-ring index developed from the drought sensitive chronology can037 showed significant and negative association between red pine growth rates and monthly drought codes (MDC) for May and August of the current fire seasons (Fig. 3). In $>90 \%$ of the fire years, the total annually burned area was a result of a single fire event. SEAs revealed generally negative departures of tree-ring index in fire years recorded in both outwash channel and sand ridge landforms (Figs. 4 and 5). Onset of negative departures was observed at the annually burned area of 30 ha for sand ridges, and at 60 ha for outwash channels. The departures reached the highest level of significance $(p<0.001)$ while considering the minimum fire size of 60 for sand ridges and of 100 ha for outwash channels. Negative exponential fitting explained $>80 \%$ of variability in growth index departures as a function of annual area burned
A.

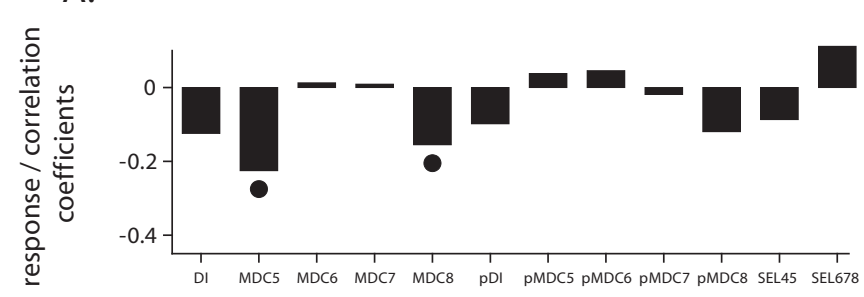

B.

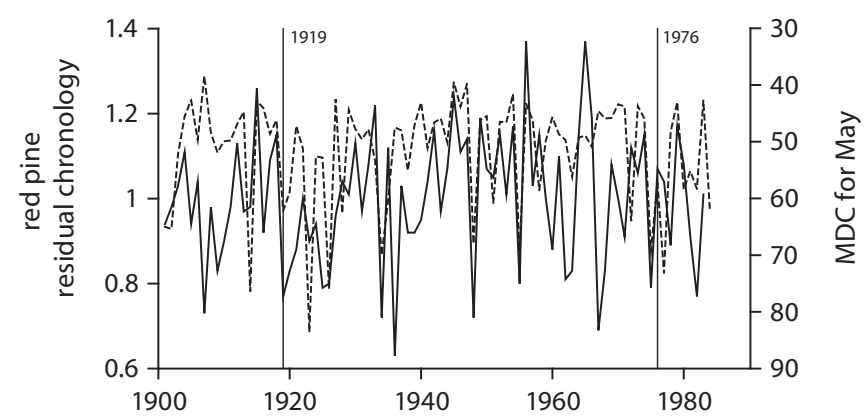

C.

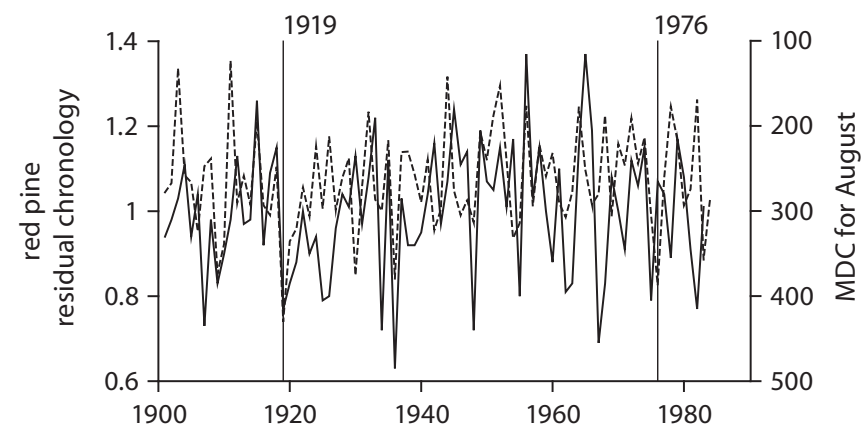

Fig. 3. Relationship between red pine chronology can037 and fire weather indexes. (A) Correlation and response function analyses of red pine chronology. Correlation values are represented by bars and significant response function values as dots below respective bars. MDC - Monthly Drought Code (Girardin and Wotton, 2009), DI - Drought Index (Prentice et al., 1993) and SEL - Seljaninov hydrothermal coefficient (Seljaninov, 1966). Numbers indicate respective calendar months for which an index was calculated. Prefix $p$ indicates the previous year fire season. B and C can037 chronology (solid line) and MDC chronologies (dashed lines) calculated for the area of Seney National Wildlife Refuge for May (B) and August (C). Two large fire years (area burned $>3000$ ha) are indicated. Note inversed OY axis on B and $C$.

threshold (Fig. 5). For the sand ridge landform the equation was:

$$
\begin{gathered}
\text { Growth index }=-0.823+\frac{1}{\exp \left(1.17 \times 10^{-2} \times \mathrm{AABF}\right)}, \\
n=16, R^{2}=83.0 \%
\end{gathered}
$$

For the outwash channel landform, the respective equation was:

$$
\begin{gathered}
\text { Growth index }=-0.515+\frac{1}{\exp (0.0105 \times \mathrm{AABF}) \times 0.674}, \\
n=18, R^{2}=83.4 \%,
\end{gathered}
$$

where AABF was annual area burned threshold, in ha.

The equations highlight the characteristic pattern of interaction between departures and fire size threshold: change in significance occurred more quickly at the beginning of the range and the amplitude of departures remained constant soon after reaching 


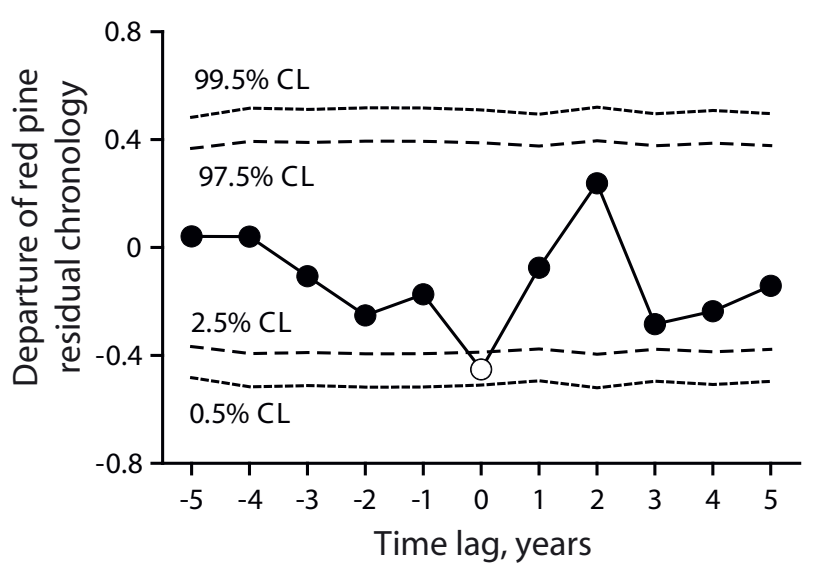

Fig. 4. Example of superimposed epoch analysis (SEA). Data: fire years with total area burned exceeding 10 ha in the sand ridges of Seney National Wildlife Refuge. Confidence Limits (CL) correspond to the 99.5 and 97.5 confidence limits for departures.
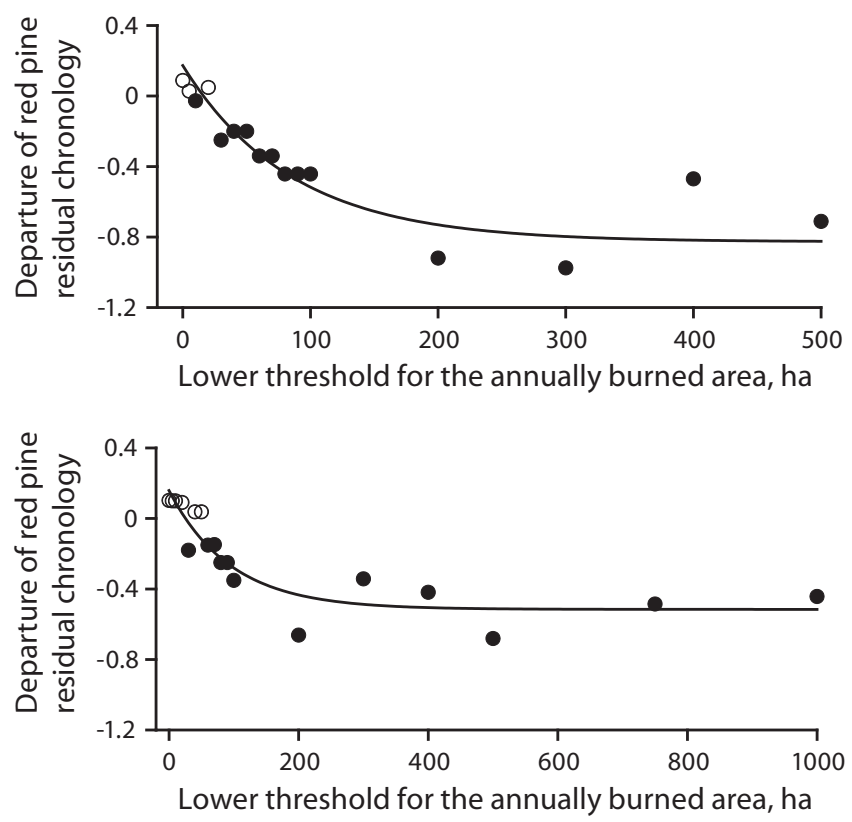

Fig. 5. Departures of residual red pine chronology (cana037) along the gradient in reconstructed annually burned areas in sand ridge (A) and outwash channel (B) dominated parts of Seney National Wildlife Refuge over 283 years (1700-1983). White, gray, and black circles refer to non-significant, significant at $p<0.05$, and significant at $p<0.01$ departures, respectively.

the threshold, a pattern which was well reflected by the negative exponential function.

We observed temporal variation in the strength of climate-fire association (Fig. 6). For three 100-year long periods centered on 1750,1900 , and 1950 the departures were negative and significant at $p<0.05$. Although departures for two other periods (i.e., centered on 1800 and 1850) were negative, their significance was $p>0.05$. Temporal pattern of large fire years revealed higher frequency of these events in the 1830s, and over 1860-1930 (Fig. 6).

\section{Discussion}

Evaluating the degree of climate forcing on historical fire events advances our understanding of indirect effects of climatic variability on forest ecosystems (Swetnam and Baisan, 1996; Meyn et al., 2007). Since instrumental records and archival information on

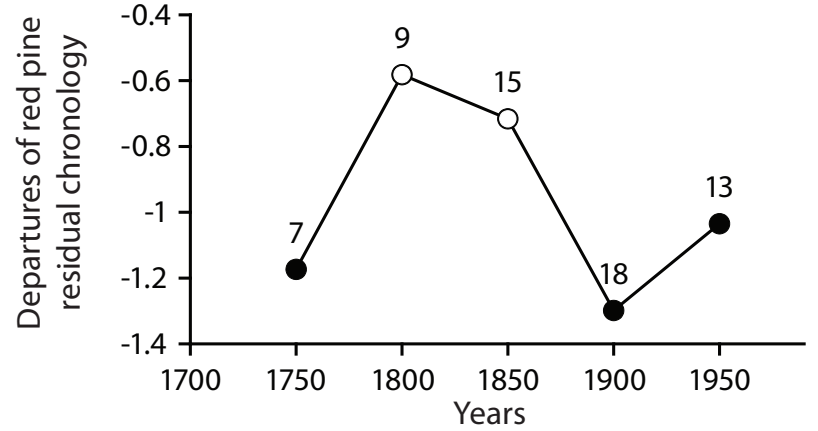

Fig. 6. Temporal dynamics of tree ring index departure at Seney National Wildlife Refuge over 1700-1983. To allow comparisons between different periods, original departures were adjusted through their division by the absolute value of the respective lower $95 \%$ percentile. Filled circles indicate significant departures at $p<0.05$ and empty circles, non-significant departures. Labels denote number of fire events reconstructed during respective time periods ( 100 years, overlapping by 50 years)

fire-related weather are rarely available over the periods exceeding the last $100-150$ years, it is the properties of the fire events themselves which could be of use to assess their climatic nature. In this study, we assumed that larger fire events would be more likely representative of climate anomalies resulting in fire conductive/conducive weather. Such anomalies would also mean drought conditions and reduced radial growth of drought-sensitive plant species (such as red pine), which allows the use of tree-ring chronologies from samples comprised such species as independent measure of fire weather in a particular year. Our study revealed an increase in the absolute values of chronology departures with the increasing annual area burned, supporting these assumptions (Fig. 5). It implied that larger fires were a product of more intensive (and probably also geographically larger) climate anomalies translating into higher water deficit and lower radial growth increment in trees used to construct the original red pine chronology.

Fire years with the area burned roughly exceeding 100 ha were likely climatically driven events over the period 1700-1983. Fires during the years below the 100 ha threshold probably developed in conditions with limited fuel conductivity and/or fire spread across the landscape. The atmospheric conditions in these years, although not excluding effective fire ignition and its limited spread, were not likely associated with large-scale drought conditions. In turn, significant statistical relationship between departures of residual chronology and years with fires above 100 ha threshold, observed on partly independent datasets (outwash channel and sand ridge landforms), suggested the same and large climatic anomalies were responsible for reduced growth in red pine at the selected site and the fires reconstructed at SNWR.

Landform features had an effect on the value of fire size threshold, although such an effect appeared limited within SNWR. Over 1700-1983, statistically significant climate-fire link was observed for fires reaching $\sim 60$ ha on the sand ridge landform and $\sim 100$ ha on the outwash channel landform. We explain this by lower fuel connectivity in the sand ridges, where fuels of a single sand ridge (1-3 ha in size, Fig. 1) can effectively remain disconnected by transitional (mesotrophic) wetlands that are typically not as conductive of fire during wetter times of the year. An area of 30 ha would mean fires developing on several islands and likely fire spread over the wetland matrix, suggesting considerable drought conditions. The 1976 Seney Fire, which originally ignited in the sand ridge dominated portion of SNWR at the end of July 1976 and burned over 22800 ha within SNWR (Anderson, 1982), could be an example of such an event. According to a nearest meteorological station at Newberry Michigan (Menne et al., 2010), summer precipitation 
for that year was the lowest for the whole period of instrumental observations (1901-2002): $140 \mathrm{~mm}$ vs. the long term average of $246 \mathrm{~mm}$. The majority of large fires at SNWR have historically been late-season fires (Drobyshev et al., 2008a), and the 1976 Seney Fire represented a general pattern of increased fire hazard within that landscape towards the end of the fire season, resulting from constant decline of water levels following spring snowmelt. In contrast, outwash channel landforms are connected in a linear fashion and have a lower density of effective fire breaks, which allows for larger fires to develop even in the absence of drought. This apparently explains higher fire size threshold for this landscape. Moreover, a decrease in water content of fuels and a general increase in fire hazard during the summer most likely makes both landform types more conductive of fire, eliminating differences between them in terms of potential for fire spread, especially during years with extreme summer droughts.

Temporal analysis of residual chronology departures highlights difficulties in identifying size threshold for climatically driven fires with certainty. The early period of 1700-1800 revealed significant departures for $>100$ ha fire years, suggesting a climate control of the fire activity as there was no history of extensive forest exploitation during that period (Karamanski, 1989; Dickmann and Leefers, 2003) and limited evidence of anthropogenic fire use by Native Americans (Loope and Anderton, 1998). Two following periods, centered on 1800 and 1850, also exhibited negative but statistically insignificant departures for $>100$ ha fire years. Properties of the datasets utilized in the analysis, onset of forest exploitation by EuroAmerican settlers and/or variability in fire weather patterns, could be important in explaining this effect. Although it is difficult to judge upon the impact of data quality, we consider them of limited role in this context. During that period, the original red pine chronology had an EPS value (expressed population signal, a statistics reflects the amount of common variance in single tree series, preserved in the master chronology, Wigley et al., 1984) above 0.94 indicating a strong common signal. Similarly, the detection probability of fire reconstruction reached the values of $0.26-0.35,0.79-0.89$, and $0.95-0.99$ for the fires 100,500 , and 1000 ha in size, respectively (see Table 1 in Drobyshev et al., 2008a). The onset of intensive forest exploitation in the eastern Upper Peninsula of Michigan (Maybee, 1960; Karamanski, 1989; Dickmann and Leefers, 2003) could be associated with additional ignition sources and harvest-related changes in forest fuels, which would disturb the linkages between climate and fire. However, we consider such an explanation unlikely. In the early 19th century the area and the structure of mixed-pine forests remained largely in their pre-EuroAmerican condition, and the overall effect of the timber harvesting was limited (Loope and Anderton, 1998; Zhang et al., 2000). The period of the most intensive logging occurred at the end of 19th century and beginning of 20th century (Dickmann and Leefers, 2003), which was instead characterized by significant relationship between the residual chronology and the fire history record. The nature of the observed pattern remains therefore unclear. PDSI reconstruction for the study area suggests generally less fire conductive weather in the first half of the 19th century (Cook et al., 2007). Less fire conductive weather might have an effect on the strength of climate-fire link, with site- and landscapespecific factors like abundance and spatial distribution of fire fuels increasing their relative importance and overriding regional climatic controls (Heyerdahl et al., 2002). However, the frequency of large fires did not exhibit clear decline during that period (Fig. 6), suggesting level of fire activity similar to the previous period, which was inconsistent with that explanation.

The period centered on 1900 showed the strongest climate-fire link among all periods considered (Fig. 6). Although an increase in fire activity at that time is commonly associated with human sources of ignitions during timber harvesting, our results suggest that large fires during 1850-1950 were likely climatically driven events with EuroAmerican ignitions dominating over lightning ignitions and, eventually, the ignitions due to Native Americans. In line with this conclusion was an increased frequency of large fires during that period (Fig. 6) and a general increasing trend in historical PDSI (Cook et al., 2004). Several prominent drought years, such as 1910 and 1920, were observed in mixed forest and boreal forest zones of Eastern North America in that period (Bergeron et al., 2004 ). For example, during the 1910 s, fires burned $>12 \%$ of the area in the transitional zone between mixed forest and coniferous boreal forest in western Quebec (Bergeron et al., 2004).

Wildfire suppression policy, introduced since the establishment of SNWR in 1935, resulted in strong reduction of the spatial extent of fire activity within the SNWR landscape (Drobyshev et al., 2008a) and modified stand dynamics in these forest ecosystems (Drobyshev et al., 2008b). In total, only three years with the area burned exceeding 100 ha were recorded since then. The statistical relationship remained, however, significant since these were the fires escaping suppression efforts or, alternatively, large prescribed fires due to strong fire-prone weather in those years.

Spatial information on historical fires may be instrumental in enhancing climatic signal in fire chronology and analyzing its temporal variation. Comparison of different time periods in respect to significance of climate-fire link also shows difficulties with reconstructing past fire histories with the help of tree-ring data. A statistical link between fire weather proxy and independently reconstructed fire events is a function of distance between sites, properties of atmospheric circulation patterns in the studied region, as well as landscape and fuel characteristics of the area. Further, although tree-ring proxy of fire weather appeared to successfully identify periods with fire-prone weather, the scale of single fire events and, therefore, estimates of the total area burned are much more uncertain. In our study, departures of residual chronology did not discriminate years with annually burned areas above 200 ha on both sand ridges and outwash channel (Fig. 5). Clearly, this indicates limits of temporal and spatial resolution of our analysis, as well as effect of study area size, which may need to be larger to better represent more regional fire activity.

\section{Conclusions}

The stochastic nature of fire activity, variation in landscape properties, and imperfect representation of fire hazard by historical proxies all complicate the task of identifying fire size thresholds, characteristic of strong weather control. Nevertheless, our results suggest 60 ha (sand ridge) and 100 ha (outwash channels) as minimum size of climatically driven fire events in the SNWR landscape. We consider such differences between major landforms as minor, taking into account the observation that many reconstructed large fires crossed the landform boundaries, suggesting that climate masked any landform-driven patterns during extreme droughts. We observed considerable temporal changes in the weather control of large fire events over 1700-1983. Although increase in fire activity at the turn of 20th century is commonly associated with human sources of ignitions, our results suggest that such an increase was likely a climatically driven episode.

\section{Acknowledgements}

Financial support for this research was provided by a grant from the Joint Fire Science Program (Project Number 05-2-1-86), the Ohio Agricultural Research and Development Center (OARDC), The Ohio State University, and Seney National Wildlife Refuge. 
Part of the salary for I.D. was provided by the Canada Research Chair in Ecology and Sustainable Forest Management, University of Québec at Abitibi-Témiscamingue, Québec, Canada. We wish to thank the staff of Seney National Wildlife Refuge for their logistical support. We also thank Stephen Rist, Bridget Deemer, Jim Downs, and Heather Whitman for assistance in the field. We thank Margaret Devall and two anonymous referees for constructive comments on earlier version of the manuscript. This paper is contribution No. 201005 from the Dendrochronological Laboratory of Swedish University of Agricultural Sciences at Alnarp. The findings and conclusions in this article are those of the authors and do not necessarily represent the views of the U.S. Fish and Wildlife Service.

\section{References}

Albert, D., 1995. Regional Landscape Ecosystems of Michigan, Minnesota, and Wiscons: A Working Map and Classification. United States Forest Service, North Central Forest Experiment Station, St. Paul, MN, 250 pp.

Anderson, S.H., 1982. Effects of the 1976 Seney National Wildlife Refuge Wildfire on Wildlife and Wildlife Habitat. Resource Publication 146. Fish and Wildlife Service. U.S. Department of Interior, Washington, DC, 27 pp.

Arseneault, D., 2001. Impact of fire behavior on postfire forest development in a homogeneous boreal landscape. Canadian Journal of Forest Research 31, 1367-1374.

Balzter, H., Gerard, F.F., George, C.T., Rowland, C.S., Jupp, T.E., McCallum, I., Shvidenko, A., Nilsson, S., Sukhinin, A., Onuchin, A., Schmullius, C., 2005. Impact of the Arctic Oscillation pattern on interannual forest fire variability in Central Siberia. Geophysical Research Letters 32.

Barnett, L., 1982. U.P. surveyors. Michigan History 66, 24-31.

Bergeron, Y., Brisson, J., 1990. Fire regime in red pine stands at the northern limit of the species range. Ecology 71, 1352-1364.

Bergeron, Y., Gauthier, S., Flannigan, M., Kafka, V., 2004. Fire regimes at the transition between mixedwood and coniferous boreal forest in Northwestern Quebec. Ecology 85, 1916-1932.

Biondi, F., Waikul, K., 2004. DENDROCLIM2002: a C++ program for statistical calibration of climate signals in tree-ring chronologies. Computers \& Geosciences 30, 303-311.

Brown, P.M., 2006. Climate effects on fire regimes and tree recruitment in Black Hills ponderosa pine forests. Ecology 87, 2500-2510.

Caprio, A.C., Swetnam, T.W., 1993. Historical fire regimes along an elevational gradient on the west slope of the Sierra Nevada, California. In: Brown, J.K., Mutch, R.W., Wakimoto, R.H., Spoon, R.W, Ronald, H. (Eds.), Proceedings: Symposium on Fire in Wilderness and Park Management: Past Lessons and Future Opportunities, March 30-April 1, 1993. Missoula, MT. 1993. Tech. Rep. INT-GTR320. Ogden, UT, U.S. Department of Agriculture, Forest Service, Intermountain Research Station. Missoula, MT.

Cary, G.J., Keane, R.E., Gardner, R.H., Lavorel, S., Flannigan, M.D., Davies, I.D., Li, C., Lenihan, J.M., Rupp, T.S., Mouillot, F., 2006. Comparison of the sensitivity of landscape-fire-succession models to variation in terrain, fuel pattern, climate and weather. Landscape Ecology 21, 121-137.

Comer, P.J., Albert, D.A., Wells, H.A., Hart, B.L., Raab, J.B., Price, D.L., Kashian, D.M., Corner, R.A., Schuen, D.W., 1995. Michigan's Native Landscape. Michigan Natural Features Inventory, Lansing, MI.

Cook, E.R., Kairiukstis, L.A., 1990. Methods of Dendrochronology. Applications in the Environmental Sciences. International Institute of Applied System Analysis/Kluver Academic Publishers, Dordrecht, Netherlands.

Cook, E.R., Meko, D.M., Stahle, D.W., Cleaveland, M.K., 1999. Drought reconstructions for the continental United States. Journal of Climate 12, 1145-1162.

Cook, E.R., Woodhouse, C.A., Eakin, C.M., Meko, D.M., Stahle, D.W., 2004. Long-term aridity changes in the western United States. Science 306, 1015-1018.

Cook, E.R., Seager, R., Cane, M.A., Stahle, D.W., 2007. North American drought: reconstructions, causes, and consequences. Earth-Science Reviews 81, 93-134.

Corace III, R.G., Goebel, P.C., Hix, D.M., Casselman, T., Seefelt, N.E., 2009. Ecological forestry at National Wildlife Refuges: experiences from Seney National Wildlife Refuge and Kirtland's Warbler Wildlife Management Area, USA. Forestry Chronicle $85,695-701$.

Dickmann, D.I., Leefers, L.A., 2003. The Forests of Michigan. The University of Michigan Press, Ann Harbor, MI.

Drobyshev, I., Goebel, P.C., Hix, D.M., Corace, R.G., Semko-Duncan, M.E., 2008a. Preand post-European settlement fire history of red pine dominated forest ecosystems of Seney National Wildlife Refuge, Upper Michigan. Canadian Journal of Forest Research 38, 2497-2514.

Drobyshev, I., Goebel, P.C., Hix, D.M., Corace III, R.G., Semko-Duncan, M.E., 2008b. Interactions among forest composition, structure, fuel loadings and fire history: a case study of red pine-dominated forests of Seney National Wildlife Refuge, Upper Michigan. Forest Ecology and Management 256, 1723-1733.

Efron, B., Tibshirani, R.J., 1993. An Introduction to the Bootstrap. Chapman \& Hall/CRC, 456 pp.
Falk, D.A., Swetnam, T.W., 2002. Scaling rules and probability models for surface fire regimes in ponderosa pine forests. In: Fire, Fuel Treatments, and Ecological Restoration: Conference Proceedings, pp. 301-317.

Flannigan, M.D., Wotton, B.M., 2001. Climate, weather, and area burned. In: Johnson, E.A., Miyanishi, K. (Eds.), Forest Fires: Behavior and Ecological Effects. Academic Press, San Francisco, CA, pp. 315-373.

Girardin, M.P., Bergeron, Y., Tardif, J.C., Gauthier, S., Flannigan, M.D., Mudelsee, M., 2006. A 229-year dendroclimatic-inferred record of forest fire activity for the Boreal Shield of Canada. International Journal of Wildland Fire 15, 375-388.

Girardin, M.P., 2007. Interannual to decadal changes in area burned in Canada from 1781 to 1982 and the relationship to Northern Hemisphere land temperatures. Global Ecology and Biogeography 16, 557-566.

Girardin, M.P., Wotton, B.M., 2009. Summer moisture and wildfire risks across Canada. Journal of Applied Meteorology and Climatology 48, 517-533.

Grissino-Mayer, H.D., Holms, R.L., Fritts, H.C., 1997. International Tree-ring Data Bank Program Library Manual. Laboratory of Tree-Ring Research, University of Arizona, Tucson, Arizona.

Heinselman, M.L., 1965. String bogs and other patterned organic terrain near Seney, Upper Michigan. Ecology 46, 185-188.

Hely, C., Bergeron, Y., Flannigan, M.D., 2000. Effects of stand composition on fire hazard in mixed-wood Canadian boreal forest. Journal of Vegetation Science 11, $813-824$

Heyerdahl, E.K., Brubaker, L.B., Agee, J.K., 2002. Annual and decadal climate forcing of historical fire regimes in the interior Pacific Northwest, USA. Holocene 12, 597-604.

Holmes, R.L., 1999. Dendrochronological Program Library (DPL). Users Manual. Laboratory of Tree-Ring Research, University of Arizona, Tucson, AZ, USA http://www.ltrr.arizona.edu/pub/dpl/.

Jonsell, M., Weslien, J., Ehnstrom, B., 1998. Substrate requirements of red-listed saproxylic invertebrates in Sweden. Biodiversity and Conservation 7, 749-764.

Karamanski, T., 1989. Deep Woods Frontier: A History of Logging in Northern Michigan. Wayne State University Press, Detroit Michigan, 305 pp.

Lecomte, N., Simard, M., Bergeron, Y., 2006. Effects of fire severity and initial tree composition on stand structural development in the coniferous boreal forest of northwestern Quebec, Canada. Ecoscience 13, 152-163.

Loope, W.L., Anderton, J.B., 1998. Human vs. lightning ignition of presettlement surface fires in coastal pine forests of the upper Great Lakes. American Midland Naturalist 140, 206-218.

Losey, E.B., 2003. Seney National Wildlife Refuge: Its Story. Lake Superior Press Marquette, MI.

Marquardt, D., 1963. An algorithm for least-squares estimation of nonlinearparameters. SIAM Journal on Applied Mathematics 11, 431-441.

Maybee II, R., 1960. Michigan's White Pine Era. Michigan Historican Commission, Lansing, MI, 55 pp.

Menne, M.J., Williams, C.N., Vose, R.S., 2010. United States historical climatology network (USHCN) Version 2. Serial Monthly Dataset. Nationa Climatic Data Center, National Oceanic and Atmospheric Administration, http://cdiac.ornl.gov/ftp/ushcn_v2_monthly/.

Meyn, A., White, P.S., Buhk, C., Jentsch, A., 2007. Environmental drivers of large, infrequent wildfires: the emerging conceptual model. Progress in Physical Geography $31,287-312$.

Morgan, P., Hardy, C.C., Swetnam, T.W., Rollins, M.G., Long, D.G., 2001. Mapping fire regimes across time and space: understanding coarse and fine-scale fire patterns. International Journal of Wildland Fire 10, 329-342.

The Midwestern Regional Climate Center (MRCC), 2007. NCDC \& the Illinois State Water Survey in Champaign, Illinois., http://mcc.sws.uiuc.edu/index.jsp.

Niklasson, M., Granström, A., 2000. Numbers and sizes of fires: long-term spatially explicit fire history in a Swedish boreal landscape. Ecology 81 1484-1499.

Prentice, I.C., Sykes, M.T., Cramer, W., 1993. A simulation model for the transient effects of climate change on forest landscapes. Ecological Modelling 65, 51-70.

Rist, S.G., 2008. Legacies of forest management and fire in mixed-pine forest ecosystems of the Seney National Wildlife Refuge, eastern Upper Michigan. A Master Thesis. The Ohio State University.

Schweingruber, F.H., Eckstein, D., Serre-Bachet, F., Bräker, O.U., 1990. Identification, presentation and interpretation of event years and pointer years in dendrochronology. Dendrochronologia 8, 9-38.

Seljaninov, G.T., 1966. Agroclimatic Map of the World. Hydrometeoizdat Publishing House, Leningrad.

Silbernagel, J., Martin, S.R., Gale, M.R., Chen, J.Q., 1997. Prehistoric, historic, and present settlement patterns related to ecological hierarchy in the Eastern Upper Peninsula of Michigan, USA. Landscape Ecology 12, 223-240.

Smirnova, E., Bergeron, Y., Brais, S., 2008. Influence of fire intensity on structure and composition of jack pine stands in the boreal forest of Quebec: live trees, understory vegetation and dead wood dynamics. Forest Ecology and Management 255, 2916-2927.

Stocks, B.J., Lynham, T.J., 1996. Fire weather climatology in Canada and Russia. In: Goldammer, J.G., Furyaev, V.V. (Eds.), Fire in Ecosystems of Boreal Eurasia. Kluwer Academic Publishers, Dordrecht, pp. 481-494.

Stocks, B.J., Mason, J.A., Todd, J.B., Bosch, E.M., Wotton, B.M., Amiro, B.D., Flannigan, M.D., Hirsch, K.G., Logan, K.A., Martell, D.L., Skinner, W.R., 2002. Large forest fires in Canada, 1959-1997. Journal of Geophysical Research: Atmospheres, 107.

Stokes, M.A., Smiley, T.L., 1968. An Introduction to Tree-ring Dating. University of Chicago Press, Chicago, IL, USA. 
Swetnam, T.W., 1996. Fire and climate history in the Central Yenisey region, Siberia. In: Goldammer, J.G., Furyaev, V.V. (Eds.), Fire in Ecosystems of Boreal Eurasia. Kluwer Academic Publishers, Dordrecht, pp. 90-104.

Swetnam, T.W., Baisan, C.H., 1996. Historical fire regime patterns in the Southwestern United States since AD 1700 USDA Forest Service. Rocky Mountain Forest and Range Experimental Station, Fort Collings, CO. USDA Forest Service. Rocky Mountain Forest and Range Experimental Station. Report RM-GTR-286. Fire effects in Southwestern Forests. In: Proceedings of the second La Mesa Fire Symposium, Los Alamos, New Mexico, March 29-31.

Turner, J.A., 1972. The Drought Code Component of the Canadian Forest Fire Behaviour System. Canadian Forest Service Publication 1316. Environment Canada, Ottawa, Ontario, Canada.
USFWS, 2009. In: Tansy, M.G., Corace III, R.G., Lindsay, G., Gale, C., Casselman, T. (Eds.), Environmental Assessment for Wildland Fire Management Plan, Seney National Wildlife Refuge. USFWS (U.S. Fish and Wildlife Service), Seney, Michigan.

Van Wagner, C.E., 1987. Development and structure of the Canadian Forest Fire Weather Index. Can. For. Serv., For. Tech. Rep. 35, 37 pp.

Wigley, T.M.L., Briffa, K.R., Jones, P.D., 1984. On the average value of correlated time series, with applications in dendroclimatology and hydrometeorology. Journal of Climate and Applied Meteorology 23, 201-213.

Zhang, Q.F., Pregitzer, K.S., Reed, D.D., 2000. Historical changes in the forests of the Luce District of the Upper Peninsula of Michigan. American Midland Naturalist $143,94-110$. 